
\section{ole}

OCTOBER 2021

RESEARCH SECTION
Allison L. Dunn

Texas A\&M University

Gary E. Briers

Texas A\&M University
Lori L. Moore Texas A\&M University

Summer F. Odom Texas A\&M University

Krista J. Bailey

Texas A\&M University

\title{
THE PLACES AND SPACES STUDENT AFFAIRS PRACTITIONERS SHOULD LEARN AND PRACTICE LEADERSHIP EDUCATOR COMPETENCIES
}

\begin{abstract}
Although leadership education typically is not explicitly incorporated into student affairs preparatory programs, student affairs practitioners are expected to facilitate the leadership development of their students. Thus, through two simultaneous Delphi panels, Group A: Student Affairs Practitioners $(n=17)$ and Group B: Student Affairs Preparatory Program Faculty $(n=20)$, this study explored the places or experiences where student affairs practitioners should learn and practice the professional competencies needed to be a student affairs leadership educator. Both expert panels agreed the graduate assistantship was the most important place to learn and practice how to be a leadership educator. Yet these findings demonstrate a gap between research and practice within student affairs preparatory programs. Four recommendations are provided to strengthen the professional preparation of student affairs practitioners as leadership educators.
\end{abstract}

\section{Introduction}

Many student affairs practitioners begin their careers in positions with a high level of direct student contact, such as advising a student organization or supervising undergraduate residence assistants or other student employees (Burkard et al., 2005). Within each of these roles are multiple opportunities for students to learn and develop their leadership capacity, making leadership development an inherent part of the student affairs practitioners' job duties. Hence, student affairs practitioners should be considered leadership educators (Dunn et al., 2019).

While it is understood that leadership education happens in student affairs contexts, a significant challenge is the absence of a consistent, standardized set of leadership competencies to teach in cocurricular leadership programs (Rosch et al., 2017).
Instead, leadership education within student affairs tends to be grounded in what the individual educator believes is leadership (Hartman et al., 2015), and what they deem important to know. That approach is highly problematic because formal coursework in leadership studies is not routinely a part of a student affairs preparatory master's degree program (Rosch et al., 2017).

Consequently, many student affairs practitioners are expected to be effective leadership educators in their first professional position without ever completing any formal leadership education or training (Dugan \& Osteen, 2016; Nelson, 2010). As a result, if they are to gain the necessary leadership competencies they endeavor to develop in their students, student affairs practitioners have to seek out leadership developmental opportunities on their own, which may or may not be research-based or grounded in 
leadership theory. A better strategy would be to gain the training and development necessary to be an effective leadership educator through formal educational means prior to their first professional position (Kuk \& Banning, 2009; Nelson, 2010). Nevertheless, the literature is extremely limited when it comes to identifying the core competencies needed to be a leadership educator in either curricular or cocurricular contexts (Jenkins \& Owen, 2016).

If the education and training should happen before the first professional position, then it logically falls to the preparatory program for that profession. However, student affairs preparatory master's programs tend to be extremely prescriptive, so simply adding a leadership studies course may not be a viable option. This challenge raises additional questions such as: What core course would a leadership studies course replace? If adding a required course in leadership studies is an unlikely option, how then should leadership education be incorporated into a student affairs master's program? And as an applied social science, does leadership development more appropriately fit into an applied context rather than an academic classroom? As Guthrie and Jenkins (2018) noted, "exploring how to best develop the capacity of leadership educators will . . . prove vital to the continued development of competent, confident, passionate, and effective leadership educators" (p. 29).

\section{Literature Review}

Regardless of the context, the central focus of leadership education is the promotion of leadership learning, where leadership is conceptualized as an amalgamation of competencies (Northouse, 2019). Truly, as Kezar and colleagues (2006) observed, "leadership is a complex, dynamic phenomenon with few quick answers or easy solutions. . . It is a longer-term investment" (p. 158). Thus, leadership education becomes the process individuals who are dedicated to their leadership learning use to develop their leadership competence over time (Guthrie \& Jenkins, 2018; Northouse, 2019).

Learning is more than the accumulation of information. Learning is an individual's holistic approach of adapting to the world around them (Kolb, 2015). King (2003) stated, "learning is both a noun and a verb, representing both an outcome and a process of education" (p. 235). As an educational outcome, learning is assessed through the possession of the competencies related to a specific field of study. Similarly, learning as an educational process relates to one's behaviors used to solve problems, gather and analyze data, process new information, and develop the strength of the arguments required when making decisions. Learning as process is influenced by the educational environment, the competencies of the teacher, the life experiences and other individual qualities of the learner, and how learners relate to and interact with other learners (King, 2003).

Research has shown that one way, if not the best way, to learn leadership is through first-hand experience (Brungardt, 1996; Buschlen \& Guthrie, 2014; Conger, 1992). Historically, leadership was learned at the college level in one of three ways: teaching in the liberal arts tradition, leadership programs with a multidisciplinary approach, and initiatives within a division of student affairs, of which the most common is student affairs (Burns, 1995; Rost \& Barker, 2000). By encouraging students to engage in both formal and informal educational opportunities, leadership educators are able to create, develop, and sustain an environment conducive to students' leadership learning (Thompson, 2013).

Discovering how to be an effective leader does not happen merely by learning leadership models, theories, or approaches; participating in workshops or attending leadership conferences; or through assuming a leadership position in an organization. Instead, learning how to become an effective leader is a life-long journey (Conger, 1992; Nelson, 2010). 
Subsequently, those who embark on this journey have to be willing to invest the time, effort, and deliberative practice needed. Practice is vital, as there is a difference between intellectually knowing what you should do in a situation and actually doing it when the situation arises (Hartman et al., 2015). In other words, avenues must be provided where individuals can connect leadership theory to practice if they are to develop the competencies needed to lead effectively (Nelson, 2010).

If leadership learning is best accomplished via deliberative practice and the typical leadership classroom does not afford the time necessary to engage in that practice, interested individuals must find alternative avenues for their practice and learning. One option is to seek experiential learning opportunities outside the classroom, because "experiential learning contributes to the time dedicated to intentional practice of actual leader behavior" (Hartman et al., 2015, p. 465). Likewise, experiential learning is the vehicle through which individuals are able to "strengthen the critical linkages among education, work, and personal development" (Kolb, 2015, pp. 3-4). Within the field of student affairs, the graduate assistantship serves as a paraprofessional rather than a research position. Consequently, the graduate assistantship is the primary experiential learning vehicle through which pre-service student affairs professionals are able to connect education, work, and professional development as they strive to put theory to practice. A second option is for instructors to increase their "emphasis on 'active' versus passive learning within their courses. [This] provides opportunities to develop the individual qualities of competence and commitment" (Astin \& Astin, 2000, p. 20).

Kolb's Experiential Learning Theory is one of the most cited theories when discussing the importance of experience or action in the process of learning and development. Kolb (2015) described experiential as a "holistic process of learning . . . that questions preconceptions of direct experience, tempers the vividness and emotion of experience with critical reflection, and extracts the correct lessons from the consequences of action" (p. xxi). Thus, an individual learns from their experiences only as they repeatedly traverse the four stages of the learning cycle: concrete experiences, reflective observation, abstract conceptualization, and active experimentation (Kolb, 2015). With each pass through the cycle, the individual deepens their understanding of the experience and gains new insights and ways to integrate what they are learning into their behavior. Therefore, "if knowledge comes from the learner's experiences, rather than from being transmitted by an 'expert,' traditional lecture-based coursework should be viewed as insufficient for teaching an applied skill like leadership" (Nelson, 2010, pp. 28-29).

The power of this cycle is found in the ability to "translate abstract ideas of academia into the concrete practical realities" of an individual's life (Kolb, 2015, p. 6), regardless of previous formal educational experience. Subsequently, those who may not excel in a traditional lecture-based classroom and have developed their own modes of learning, or those who require relevance and applicability of concepts before integration, benefit from use of the experiential learning cycle, as they are able to employ their past experiences in their continued personal development (Kolb, 2015). Additionally, in applied fields such as leadership studies and student affairs, experiential learning is important as a means to bridge theory and practice, enhance the development of needed competencies, and provide opportunities for students to practice their developing leadership skills and abilities (Nelson, 2010).

This focus on experiential learning, practice, and feedback as a means of leadership learning is found within student affairs preparatory programs. As applied social and behavioral sciences, leadership studies and student affairs align nicely and the learning of students engaged in these fields of study is amplified through experiential learning (Nelson, 2010). Hartman et al. (2015) found that co-curricular learning opportunities, like those in student affairs programs and which pre-service student affairs professionals engage in through their graduate assistantships, incorporated all four of Conger's 
necessary dimensions ofleadershiplearning(personal growth, conceptual understanding, feedback, and skill building). Student affairs preparatory program faculty also assumed pre-service student affairs practitioners were learning leadership skills through their assistantship role and responsibilities, although the learning was not monitored nor measured (Rogers, 1991).

Student affairs preparatory programs tend to offer a prescriptive course of study, where the program administrators dictate the courses the students must take as well as the order (Herdlein et al., 2013; Hyman, 1985). Consequently, this approach creates a cohort of students and a generalist degree, where students gain a broad overview of what is needed to be successful in any entry-level student affairs position. This breadth of subject matter comes at the price of depth in any one functional area within student affairs. If a student desires a deeper understanding of a specific functional area, such as student activities or recreation sports, then they must seek it out through experiential learning opportunities, such as graduate assistantships, internships, or practica.

Over time, the roles and focus of student affairs practitioners have shifted from a service mindset, (e.g. staffing dining halls, overseeing residence halls, and career counseling) to one of education and development. But, the focus of all student affairs positions remains constant, the development of the whole person (Nuss, 2003). Accordingly, most student affairs divisions have two basic goals: "(1) to provide cocurricular programs, activities, and other learning opportunities that contribute to . . . students by meeting their academic, social, recreational, physical, emotional, and moral development needs and (2) to promote self-direction and leadership among those students" who are involved on campus (Javinar, 2000 , p. 86). Hence, "many student affairs programs emphasize leadership education as an essential part of student development" (Burns, 1995, p. 244).
Researchers agree student affairs practitioners are educators (Moore \& Marsh, 2007) as the purpose of their profession is to assist in the holistic development of students (Blake, 2007; Coffey, 2010). In fact, student affairs professionals are expected to educate and promote leadership in their students (Burns, 1995; Javinar, 2000) as intentional partners with academic affairs (Herdlein, 2004). But how do student affairs practitioners learn to be effective leadership educators?

The literature is replete with studies focused on the necessary competencies to be an effective student affairs professional (e.g. Burkard et al., 2005; Dickerson et al., 2011; Herdlein et al., 2013), but the analysis of the competencies needed to be an effective student affairs leadership educator is an emerging area of research. One of the fist studies to explore this topic detailed over 40 necessary leadership educator competencies for student affairs practitioners (Dunn et al., in press). Figure 1 details a selection of the highest-ranking leadership educator competencies, as reported by Dunn et al., (in press). 
Figure 1.

Selected Leadership Educator Competencies Needed by Entry-level Student Affairs Practitioners.

\begin{tabular}{ccc} 
Knowledge Domain & Skills Domain & Abilitites/Attributes Domain \\
\hline Experiential learning & Self-awareness & Learn from one's mistakes \\
\hline Community building & Reflection & Trustworthiness \\
\hline $\begin{array}{c}\text { Deep understanding of diversity, inclusion, } \\
\text { privilege, opression, and power dynamics }\end{array}$ & Problem-solving & Respect for all students \\
\hline Student development theory & Critical thinking & Communicate across differences \\
\hline The college environment & Effective communication & Be an ethical decision maker \\
\hline
\end{tabular}

*Note. Adapted from “Necessary Leadership Educator Competencies for Entry-level Student Affairs Leadership Educators" by Dunn, A. L., Moore, L. L., Odom, S. F., Briers, G. E, \& Bailey, K. J. in press, Journal of Leadership Education. Copyright (in press) by the Association of Leadership Educators.

However, where these competencies should be learned and practiced has yet to be explored. This demonstrates a gap in the literature and provides the rationale for this study. Therefore, the purpose of this study, as part of a larger study, was to explore how and where pre-service student affairs practitioners should learn and gain experience with the leadership educator competencies as identified by Dunn et al., (in press). This study was guided by the following overarching research question: How and where should entry-level student affairs practitioners gain competence as leadership educators?

\section{Methods}

When wanting to elicit and refine group opinions or judgements on a topic or subject, it is appropriate to use a classic Delphi technique to engage experts in that topic (Buriak \& Shinn, 1989; Dalkey, 1969a; Delbecq et al., 1975; Franklin \& Hart, 2007; Linstone \& Turoff, 1975). For this study, the topic to be explored and refined was the places or experiences needed for entry-level student affairs practitioners to gain competence as leadership educators. Research has detailed that student affairs practitioners and faculty members view the competencies needed to be a successful student affairs practitioner differently (Hyman, 1985; Kuk et al., 2007; Miles, 2007). Therefore, a diverse group of those who teach and train pre-service student affairs professionals were called upon to serve as the qualified experts and share their perspectives (Dalkey 1969a; Delbecq et al., 1975; Rayens \& Hahn, 2000).

Population. As the student affairs professionals who most closely work with entry-level practitioners and the changing needs of students who use their programs or services, student affairs practitioners/ mangers provide a unique perspective of the competencies needed to be successful student affairs professionals. As Burkard et al. (2005) noted, "no one may be better positioned to help us understand the necessary entry-level competencies of a student affairs professional than those individuals who recruit, select, hire, and supervise such staff members" (p. 286). But student affairs managers are not the only ones whose perspective influences 
what it takes to be a successful student affairs practitioner. Those who teach in and direct student affairs preparatory programs also provide valuable insight and perspective into the competencies needed to be successful in this profession (Hyman, 1985). Individually, each perspective is valid and important, but provides an incomplete analysis of what it takes to be a successful student affairs leadership educator. Both perspectives were needed to gain a better understanding of where professional competencies should be learned and practiced. Accordingly, two separate context-specific Delphi panels were conducted simultaneously: Group A Student Affairs Practitioners and Group B - Student Affairs Preparatory Program Faculty Directors.

Because a master's degree is generally required for full-time employment as a student affairs practitioner (Nelson, 2010), the population was narrowed to include only master's level student affairs preparatory programs. However, not all master's programs are the same. These programs vary in length of study, curriculum delivery, and degree offered. Traditionally, a student affairs preparatory program is a two-year, residential program with a required clinical paraprofessional practice such as an assistantship, internship, or practicum. Therefore, to be representative of the traditional program, only program directors of two-year, residential master's programs with a required clinical practice component were invited to participate.

Although the findings of this study are directed toward entry-level student affairs practitioners, they were not included in the population. As is the case with many new employees, entry-level student affairs practitioners do not always know, nor do they always possess, the competencies needed to be successful in their chosen profession (Roberts, 2003). While they are expected to effectively make use of their graduate education from their first day on the job post-master's degree, research has shown that recent student affairs preparatory program graduates may not be sufficiently prepared to do so (Nelson, 2010). Thus, sampling entry-level student affairs practitioners may not provide reliable data, as entry-level professionals do not always know what they do not know.

A central tenant of the Delphi method is the purposive selection of experts. Only those who have substantial experience or expertise in the subject matter in question are invited to be part of the panel of experts (Delbecq et al., 1975; Linstone \& Turoff, 1975; Morgan et al., 2013; Rayens \& Hahn, 2000). The weight of their experience or expertise is such that their opinions or judgements are viewed as credible within their discipline or profession and representative of said discipline or profession (Delbecq, et al., 1975; Franklin \& Hart, 2007).

The selection of panelists occurred through the use of a sampling frame. As leadership education within student affairs was the topic under exploration, panelists needed to have demonstrated experience or expertise in (a) student affairs as a profession and (b) the leadership development of college students. Demonstrated experience or expertise was determined as meeting at least three of the five criteria listed below.

1. Three or more years of experience as a full-time student affairs practitioner or researcher

2. Three or more years of experience with college student leadership development

3. Three or more years supervising entry-level student affairs practitioners

4. Three or more years of experience as a preparatory student affairs program director/coordinator

5. Three or more years teaching in a preparatory student affairs master's program

Two Samples. When dealing with group opinions, a common point of view is that larger groups provide better results. Yet, Dalkey (1969b) found that 13 was the minimum number of individuals needed to represent a larger group and satisfy process reliability at 0.80 . The initial recruitment goal was 17-20 participants in each context-specific panel in anticipation of participant attrition, and to maintain 
a minimum of 13 members in each panel by the final round. Invitations to participate ceased once each panel met the participant recruitment goal.

Seven journals between the years of 2008 and 2018 were searched to identify potential participants (the Journal of Student Affairs Research and Practice, Journal of College Student Development, Journal of Leadership Education, College Student Journal, NASPA Journal, College Student Affairs Journal, and Research and Practice in Assessment). The focus of the search was articles related to the necessary competencies for student affairs practitioners or leadership education in student affairs. Authors who met the participant criteria were invited to take part in the study. They were also asked to nominate a student affairs preparatory program director or student affairs practitioner who met the selection criteria.

This process identified 89 individuals who were invited to participate. Thirty-two student affairs practitioners were invited, and 17 agreed to participate (Group A). All 17 were employed at public institutions at the time of the study and had experience in a variety of functional areas within student affairs. Predictably, attrition occurred over the course of the study (17 to 13). Similarly, 57 student affairs preparatory program faculty members were identified and invited. Ten faculty members agreed to participate (Group B), which did not meet the minimum needed for a full panel. Therefore, the ACPA online directory was searched, which generated 10 additional preparatory program directors who agreed to participate in the study. Both public and private institutions were represented, and all 20 panelists held a higher education/student affairs faculty appointment at the time of the study. Again, as expected, attrition occurred over the course of the study (20 to 15 ). Demographics were not included, as the predetermined selection criteria for expertise is used to describe Delphi participants (Dalkey, 1969b).

Instrumentation. To maximize the range of responses (Schmidt, 1997), and to address the overarching research question guiding this study, both panels were asked the same open-ended query: Where should entry-level student affairs practitioners learn and practice leadership educator competencies? Each panel reached stabilization on all items after three rounds.

For Round 1, each panelist was sent an email with a unique link to the initial online Qualtrics survey. Using content analysis techniques (Merriam \& Tisdell, 2016), the responses for each panel were analyzed separately. Within each panel, similar statements were pooled, and compound statements were divided. All unique statements were added to the panel-specific Round 2 survey (Linstone \& Turoff, 1975).

For Round 2, only those who completed round 1 were emailed a personalized link to the panel-specific Round 2 survey. Using a 5-point response scale, (1 = Not at all Important to 5 = Extremely Important), panelists were asked to rate the importance they associated with each statement (Delbecq et al., 1975; Linstone \& Turoff, 1975). Panelists were given the opportunity to include other item(s) they believed important at the end of each section.

For Round 3, frequency distributions were used to sort and analyze the responses from round 2 (Buriak \& Shinn, 1989). In efforts to maximize the data, any item where at least $50 \%$ of the participants ( $n a \geq 8$; nb $\geq 7$ ), set a priori, responded 'very important' (rating of 4) or 'extremely important' (rating of 5) were advanced to round 3 (Okoli \& Pawlowski, 2004; Schmidt, 1997). The personalized Round 3 surveys included the panelist's round 2 rating for each item, as well as the frequencies and counts of the other panel members who responded 'very important' or 'extremely important' for each item. Panelists were given the opportunity to change their rating to 'moderately important,' 'very important,' or 'extremely important,' or keep it as is. Any 'other' statements from round 2 were included at the end of the applicable section for initial rating. Panelists were asked to use the same 5-point response scale as in round 2. Consensus was defined as any item with a supermajority summative rating of at least $75 \%$ of 'very important' (rating of 4 ) 
and 'extremely important' (rating of 5 ) at the end of round 3 ( $n a \geq 10 ; n b \geq 12$ ), set a priori.

\section{Research Approach and Analysis}

We used an interpretive, qualitative research design (Merriam \& Tisdell, 2016). Using an inductive process, data were gathered and then analyzed to identify each unique place where pre-service student affairs practitioners should learn or practice the competencies needed to be a student affairs leadership educator. Descriptive statistics can be used to determine patterns and describe relationships between groups (Fraenkel \& Wallen, 2009). Thus, descriptive statistics, including frequencies and counts, were used to determine the items carried forward between Delphi rounds, consensus within each panel (Rayens \& Hahn, 2000), and comparisons between panels. Agresti and Finlay (2009) also detailed that descriptive statistics can be used to determine differences in attitudes of separate and unique groups. The lack of variance in the opinions of the panelists is one way to measure consensus or item stability (Crisp et al., 1997). The Texas A\&M University Institutional Review Board approved this study.

\section{Findings}

As previously stated, the research question driving this study was: How and where should entry-level student affairs practitioners gain competence as a leadership educator? To address this larger question, all panelists were asked the following, more specific query in the Round 1 survey: Where should entrylevel student affairs practitioners learn and practice leadership educator competencies?

Group A: Student Affairs Practitioners. At the conclusion of round 1, Group A panelists had identified 44 places where student affairs practitioners should learn and practice leadership educator competencies, all of which were included in the Round 2 survey. The Round 2 survey was divided into component-specific blocks to reduce participant fatigue and increase readability: necessary places to learn leadership educator competencies (23 items) and necessary places to practice them (21 items). Only one of the Group A panelists chose not to change any of their round 2 responses. At the close of round 3, 84.62\% of the responses $(n=374)$ remained the same as in round 2 . Of the responses that changed, $79.41 \%(n=$ 54) were rated at a higher level of importance. Having a majority of the change directed towards increased importance stresses the previous value designated by the panelists and is an indicator of stability in the data.

Table 1 details the places where student affairs practitioners should learn leadership educator competencies, according to Group A panelists. Items are organized in descending order of round 3 frequency counts. The summated 'important' and 'extremely important' responses for each item are detailed. Of the 23 places to learn items generated from round 1 and rated in round 2, 14 places were advanced to round 3 . The items not forwarded are included in Table 2. Five 'other' items were initially rated in round 3 , but none met the criteria to be regarded as necessary. In the end, the Group A experts identified six necessary places to learn leadership educator competencies. Professional development workshops or trainings, coordinated either within their institution or through professional associations, were mentioned initially; however, both places failed to reach the criteria for advancement in the study and subsequently were not deemed necessary places. Given that experience with undergraduate leadership development was part of the selection criteria for Group A experts, it was surprising that participating in a leadership program as an undergraduate student did not advance through the Delphi process (see Table 2).

Table 3 details the places where student affairs practitioners should practice leadership educator competencies, according to Group A panelists. Items are organized in a similar manner to Table 1. Of the 21 items generated from round 1 and rated in round 2, 14 were advanced to round 3 . The items not forwarded to round 3 are included in Table 4. 
Table 1.

Descriptive Statistics of Where to Learn Leadership Educator Competencies: Student Affairs Practitioners (Round 2, $N=14 ;$ Round 3, $N=13$ )

\begin{tabular}{llcc} 
& \multicolumn{3}{c}{ Responses \% (f) } \\
Item & Round 2 & Round 3 & Rank Order \\
$\begin{array}{l}\text { Graduate assistantship in any office that integrates leadership } \\
\text { learning }\end{array}$ & $100.0(14)$ & $100.0(13)$ & 1 (tied) \\
\hline On the first job post-master's & $100.0(14)$ & $100.0(13)$ & 1 (tied) \\
\hline Previous mentoring relationships & $92.9(13)$ & $92.3(12)$ & 3 \\
\hline A required course in master's coursework & $85.7(12)$ & $84.6(11)$ & 4 (tied) \\
\hline Internship and/or practicum & $78.6(11)$ & $84.6(11)$ & 4 (tied) \\
\hline Being mentored by senior leadership educator & $71.4(10)$ & $76.9(13)$ & 6 \\
\hline Formal leadership course in master's program* & $71.4(10)$ & $69.2(9)$ & \\
\hline Graduate advisor to a student organization* & $71.4(10)$ & $69.2(9)$ & \\
\hline Team participation* & $71.4(10)$ & $69.2(9)$ & \\
\hline Undergraduate extra-curricular activities* & $64.3(9)$ & $61.5(8)$ & \\
\hline Involvement with professional associations* & $57.1(8)$ & $61.5(8)$ & \\
\hline Professional development training (external)* & $50.0(7)$ & $53.8(7)$ & \\
\hline Workshops or trainings (internal)* & $50.0(7)$ & $53.8(7)$ & \\
\hline Involvement on campus committees in the field* & $50.0(7)$ & $53.8(7)$ & \\
\hline Communities of practice* & Not rated & $53.8(7)$ & \\
\hline Community engagement and volunteering* & Not rated & $38.5(5)$ & \\
\hline Leadership Educator Professional Identity Development Model* & Not rated & $30.8(4)$ & \\
\hline Part-time or full-time employment* & Not rated & $23.1(3)$ & \\
\hline Campus book club or working group* & Not rated & $15.4(2)$ & \\
\hline
\end{tabular}

*Item did not meet the $75 \%$ supermajority at the end of round 3 and was not considered in final

\section{Table 2.}

Descriptive Statistics of Identified but Not Advanced Places to Learn Leadership Educator Competencies: Student Affairs Practitioners (Round 2, N=14)

Participating in leadership programs as undergraduates

$42.9(6)$

Prior employment

$42.9(6)$

Participation in professional leadership conference (ILA or LEI/NCLP)

$42.9(6)$

Group work in the classroom

$35.7(5)$

Volunteering and community service

$35.7(5)$

Reading journals or books seminal to the discipline

$35.7(5)$

Participating in the Multi-institutional Study of Leadership (MSL) research

$21.4(3)$

Presenting at professional conferences

$14.3(2)$

Their undergraduate classes

$14.3(2)$ 
Only one 'other' item was identified in round 2 and advanced to round 3 for initial rating. Ultimately, 11 places met the criteria to be identified as necessary places to practice leadership educator competencies, including one 'other' place identified in round 2 . The limited importance Group A experts placed on participating in undergraduate leadership programs continued, as it was not considered a necessary place to practice leadership educator competencies either (see Table 4).

\section{Table 3.}

Descriptive Statistics of Where to Learn Leadership Educator Competencies: Student Affairs Practitioners (Round 2, $N=14 ;$ Round $3, N=13$ )

\begin{tabular}{lccc} 
& \multicolumn{3}{c}{ Responses \% (f) } \\
Item & Round 2 & Round 3 & Rank Order \\
\hline Graduate assistantship & $92.8(13)$ & $100.0(13)$ & 1 (tied) \\
\hline Internship and/or practicum & $92.9(13)$ & $100.0(13)$ & 1 (tied) \\
\hline On the first job post-master's & $78.6(11)$ & $100.0(13)$ & 1 (tied) \\
\hline Team participation & $78.6(11)$ & $92.3(12)$ & 4 (tied) \\
\hline Graduate advisor to a student organization & $64.3(9)$ & $92.3(12)$ & 4 (tied) \\
\hline Communicating across differences & Not rated & $92.3(12)$ & 4 (tied) \\
\hline Identify something they are passionate about greater than themselves & $71.5(10)$ & $84.6(11)$ & 7 \\
\hline Volunteering and community service & $64.3(9)$ & $76.9(10)$ & 8 (tied) \\
\hline Previous mentoring relationships & $71.5(10)$ & $76.9(10)$ & 8 (tied) \\
\hline Formal class in master's program & $64.3(9)$ & $76.9(10)$ & 8 (tied) \\
\hline Group work in the classroom & $64.3(9)$ & $76.9(10)$ & 8 (tied) \\
\hline Involvement in professional organizations* & $64.3(9)$ & $69.2(9)$ & \\
\hline Involved on campus committees* & $57.1(8)$ & $69.2(9)$ & \\
\hline A required course in master's coursework* & $64.3(9)$ & $61.5(8)$ & \\
\hline Professional development training (external)* & $50.0(7)$ & $53.8(7)$ & \\
\hline Community engagement and volunteering* & Not rated & $38.5(5)$ & \\
\hline Leadership Educator Professional Identity Development Model* & Not rated & $30.8(4)$ & \\
\hline Part-time or full-time employment* & Not rated & $23.1(3)$ & \\
\hline Campus book club or working group* & Not rated & $15.4(2)$ & \\
\hline
\end{tabular}

*Item did not meet the $75 \%$ supermajority at the end of round 3 and was not considered in final 
Table 4.

Descriptive Statistics of Identified but Not Advanced Places to Practice Leadership Educator Competencies: Student Affairs Practitioners (Round 2, N=14)

Item Responses \% (f)

Presenting at professional conferences

$42.9(6)$

\begin{tabular}{ll}
\hline Attend leadership conference (ILA, LEI, NCLP) & 42.9 (6) \\
\hline Prior employment & $35.7(5)$ \\
\hline Workshops or trainings (internal) & $35.7(5)$ \\
\hline Participating in leadership program in college & $35.7(5)$ \\
\hline Their undergraduate extracurricular activities & $35.7(5)$ \\
\hline Their undergraduate classes & $28.6(4)$ \\
\hline Presenting at professional conferences & $14.3(2)$ \\
\hline Their undergraduate classes & $14.3(2)$ \\
\hline
\end{tabular}

Group B: Student Affairs Faculty. At the conclusion of round 1, Group B panelists had identified 36 unique places to learn and practice leadership educator competencies, which were included in the Round 2 survey. Similar to the Round 2 survey for Group A, the Round 2 survey for Group B was divided into component-specific blocks: necessary places to learn leadership educator competencies (20 items) and necessary places to practice them (16 items). At the end of round 3, 91.6\% of the responses $(n=371)$ did not change. Of the responses that did change, 85.3\% ( $n=29$ ), were rated at an even higher level of importance. Thus, emphasizing the value the panelists had given to these items previously and signifying the stability of the data.

Table 5 details the places where student affairs practitioners should learn leadership educator competencies, according to Group B panelists. Once again, items are organized similarly to Table 1, and the summated 'important' and 'extremely important' responses for each item are detailed. Of the 20 items generated from round 1 and rated in round 2 , 13 items were advanced to round 3 . The items not forwarded are included in Table 6. The one 'other' item identified in round 2 was advanced to round 3 for initial rating, but did not meet the criteria to be considered a necessary place. In the end, eight places were deemed necessary to learn leadership educator competencies. It is worth noting that the student affairs faculty experts did not characterize either participating in or leading student organizations as necessary places to learn competencies needed to be a student affairs leadership educator (see Table 6). 
Table 5.

Descriptive Statistics of Where to Learn Leadership Educator Competencies: Student Affairs Preparatory Program Faculty (Round 2, N= 16; Round 3, N=15)

\begin{tabular}{lccc} 
& \multicolumn{3}{c}{ Responses \% (f) } \\
Item & Round 2 & Round 3 & Rank Order \\
\hline Graduate assistantship & $100.0(16)$ & $100.0(15)$ & 1 (tied) \\
\hline Core course in master's program & $100.0(16)$ & $100.0(15)$ & 1 (tied) \\
\hline On the job training post master's degree & $93.8(15)$ & $100.0(15)$ & 1 (tied) \\
\hline Graduate practicum(a) & $87.5(14)$ & $100.0(15)$ & 1 (tied) \\
\hline Elective course in master's program & $93.8(15)$ & $93.3(14)$ & 5 (tied) \\
\hline Engaging teaching methods & $87.5(14)$ & $93.3(14)$ & 5 (tied) \\
\hline Internships & $81.3(13)$ & $93.3(14)$ & 5 (tied) \\
\hline Being mentored & $75.0(12)$ & $81.3(13)$ & 8 \\
\hline $\begin{array}{l}\text { Professional development opportunities off-campus (professional } \\
\text { associations)* }\end{array}$ & $62.5(10)$ & $66.7(10)$ & \\
\hline $\begin{array}{l}\text { Professional development opportunities on-campus (workshops/ } \\
\text { trainings)* }\end{array}$ & $56.3(9)$ & $66.7(10)$ & \\
\hline Reading current leadership journals/books* & $56.3(9)$ & $66.7(10)$ & \\
\hline Side conversations before, after, or during meetings* & $50.0(8)$ & $60.0(9)$ & \\
\hline Employment (non-assistantship)* & $50.0(8)$ & $60.0(9)$ & \\
\hline Attending conferences* & Not rated & $40.0(6)$ & \\
\hline
\end{tabular}

*Item did not meet the $75 \%$ supermajority at the end of round 3 and was not considered in final

\section{Table 6.}

Descriptive Statistics of Identified but Not Advanced Places to Learn Leadership Educator Competencies: Student Affairs Preparatory Program Faculty (Round 2, N=16)

\section{Item}

Responses \% (f)

In daily interactions

$31.3(5)$

Participation in student organization (student leader)

$31.3(5)$

Facilitate leadership trainings or workshops

$25.0(4)$

Participation in student organization (member)

$25.0(4)$

Mentoring others

$25.0(4)$

Co-author journal articles

$6.3(1)$

Teach a leadership course

$6.3(1)$ 
Table 7 details the places student affairs practitioners should practice leadership educator competencies, according to Group B panelists. Items are organized similarly to Table 3. Of the 16 items generated from round 1 and rated in round 2, 11 were advanced to round 3 . The items not forwarded are included in Table 8. Two 'other' items were advanced to round 3 for initial rating, but neither met the criteria to be necessary. Seven places met the criteria to be considered necessary places to practice leadership educator competencies.

\section{Table 7.}

Descriptive Statistics of Where to Practice Leadership Educator Competencies: Student Affairs Preparatory Program Faculty (Round 2, N= 16; Round 3, N=15)

\begin{tabular}{lccc} 
& \multicolumn{3}{c}{ Responses \% (f) } \\
Item & Round 2 & Round 3 & Rank Order \\
Graduate assistantships & $100.0(16)$ & $100.0(15)$ & ( (tied) \\
\hline Graduate internship(s) or practicum(a) & $100.0(16)$ & $100.0(15)$ & 1 (tied) \\
\hline On the job & $93.8(15)$ & $93.3(14)$ & 3 (tied) \\
\hline $\begin{array}{l}\text { Helping students understand and engage in challenges to defend } \\
\text { their beliefs/core values }\end{array}$ & $81.3(13)$ & $93.3(14)$ & 3 (tied) \\
\hline Engaging in professional communities & $87.5(14)$ & $86.7(13)$ & 5 (tied) \\
\hline Advising student groups & $68.8(11)$ & $86.7(13)$ & 5 (tied) \\
\hline Creating and/or facilitating a campus event/program & $62.5(10)$ & $86.7(13)$ & 5 (tied) \\
\hline In the graduate classroom* & Not rated & $73.3(11)$ & \\
\hline Presenting at professional conferences* & $56.3(9)$ & $60.0(9)$ & \\
\hline Training student leaders* & $50.0(8)$ & $60.0(9)$ & \\
\hline Representing an office on a campus committee* & $50.0(8)$ & $53.3(8)$ & \\
\hline $\begin{array}{l}\text { Involvement in campus activities beyond class and graduate } \\
\text { assistantships* }\end{array}$ & $50.0(8)$ & $53.3(8)$ & \\
\hline Participation in webinars* & Not rated & $6.7(1)$ & \\
\hline
\end{tabular}

*Item did not meet the $75 \%$ supermajority at the end of round 3 and was not considered in final 
Table 8.

Descriptive Statistics of Identified but Not Advanced Places to Practice Leadership Educator Competencies: Student Affairs Preparatory Program Faculty (Round 2, N=16)

Through interpersonal interactions

Mentoring others

$37.5(6)$

Taking student leaders to professional conferences $18.8(3)$

Volunteering in the local community

$12.5(2)$

Actively working to enhance the off-campus community

$12.5(2)$

\section{Conclusions}

If the goal is to prepare competent student affairs leadership educators who are able to develop the next generation of effective leaders, it is not enough to know the professional competencies needed to be a leadership educator, which were identified by Dunn et al., (in press). One must also understand the ideal places where student affairs practitioners should learn and practice these competencies. Identifying these places helps clarify the individual roles and responsibilities student affairs faculty and practitioners have in the preparation and development of the next generation of student affairs leadership educators.

Where to Learn Leadership Educator Competencies. There was considerable overlap between the lists of both expert panels, which speaks to the stability of the data. Each of the six necessary places to learn leadership educator competencies identified by the Practitioners (Group A) were also identified by the Preparatory Program Faculty (Group B); with the Faculty identifying two additional places to learn the competencies. Ranking the graduate assistantship as the most important place to learn leadership educator competencies was not unexpected as requiring a graduate assistantship was part of the inclusion criteria for the preparatory program, and subsequently the program faculty director. However, since there are student affairs preparatory programs that do not require a graduate assistantship, the inference space for this finding is limited.
There was also overlap in the places considered by both panels not to be necessary for learning these competencies. Specifically, participation in professional development training was seen by both panels as an ineffective place to learn leadership educator competencies. This could be because both groups recognize that one cannot master the professional competencies needed to be a student affairs leadership educator in an afternoon or in a contrived situation or scenario. Additionally, both panels considered participating in campus activities, like student organizations or leadership programs as unnecessary places to learn the competencies needed to be a student affairs leadership educator. One possible explanation could be that both expert panels believe the student affairs practitioners who coordinate or advise these groups are not competent leadership educators themselves. Thus they cannot effectively teach or train others on competencies they do not personally possess.

Although there were considerable similarities between both generated lists, there were some subtle differences. A core course in leadership studies was identified as necessary by both panels, yet the Faculty experts (Group B) also included an elective leadership studies course as a necessary, but less important, place to learn these competencies. Identifying both a core and an elective course in leadership studies shows the value the Faculty experts place in learning leadership educator competence in an academic setting. In essence, they are saying it is 
good to offer an elective course in leadership studies within the preparatory student affairs program, but it is better to require the leadership studies course. This finding is important to note because the Faculty experts are saying one thing-a leadership studies course should be required in preparatory student affairs programs-but doing the opposite, as very few programs incorporate a leadership studies course into the elective, let alone the core, curriculum. One possible explanation for this disconnect could be the time needed to route academic program changes through university approval systems. It could be that proposals to add leadership studies courses to student affairs preparatory programs are in process, but have yet to be approved or implemented.

Both lists indicated it is preferred to learn leadership competencies on the job post master's degree. All other items on both lists were tied directly to various aspects of an academic student affairs preparatory program. This item supports previous research that one of the best ways to learn leadership is through first-hand experience (Brungardt, 1996; Buschlen \& Guthrie, 2014; Conger 1992; Hall, 2014). By extension then, one of the best ways to learn the competencies needed to be a leadership educator is by working as a leadership educator. But research has shown that the best place to develop professional competencies is during one's academic preparatory program, not on the job (Kuk \& Banning, 2009; Nelson, 2010). Moreover, research has also shown that entrylevel student affairs practitioners lack many of the professional competencies needed to be successful as they begin their first job post-master's degree (Nelson, 2010; Roberts, 2003). These findings raise additional questions: is it too much to expect new professionals to learn and develop the specialized competencies of leadership education in addition to the other professional competencies they lack? By placing these expectations on early-career practitioners, are they being set up for failure or at least burnout? Could these unrealistic expectations be one of the causes for the high number of earlycareer student affairs practitioners who leave the profession?
Where to Practice Leadership Educator

Competencies. Conversely, in relation to places where entry-level student affairs practitioners should practice leadership educator competencies, there was not a great degree of overlap between the two panels. Only four items, (graduate assistantship, on the job, graduate internship and/or practica, and advising a student organization) were identified by both expert panels. Three of those four common items (all but advising a student organization) were ranked as the most important places to practice leadership educator competencies, again signifying the stability of the data. As was the case with where to learn leadership educator competencies, the graduate assistantship was identified as the most important place to practice leadership educator competencies.

Because a student affairs graduate assistantship, internship, or practicum mirrors the work of full-time student affairs practitioners, it was not unexpected that these places were identified as some of the most important places to practice leadership educator competencies. Each takes an experiential approach to learning with the goal being translating theory to practice. But proficiency comes through extensive, intentional practice and trial and error; therefore, waiting to practice the competencies until one is hired in that first full-time job may not be wise, as the margin for error and acceptance of a 'trial and error approach' shrinks with full-time staff member status.

It is of interest that only the Practitioners (Group A) identified an academic setting as a necessary place to practice leadership educator competencies. This panel selected two items, a formal class in leadership within the master's program (less important) and group work within the classroom (more important), even though they are not responsible for what occurs in the preparatory program courses. Considering that the Faculty (Group B) are primarily responsible for teaching the history and practice of student affairs as a profession, it is reasonable that they do not consider a generalist academic classroom an appropriate venue in which to practice leadership educator competencies. All of the remaining places 
to practice these competencies identified by both Delphi panels revolved around 'learning by doing' in non-academic settings, which denotes the applied nature of leadership and the benefit of requiring experiential learning opportunities in student affairs preparatory programs as the preferred avenues to learn and practice the professional competencies of a student affairs leadership educator.

\section{Recommendations}

The analysis of the data led to four recommendations, which have implications for the professional preparation and further study of student affairs leadership educators.

\section{A course in leadership studies should be included in the curriculum of student affairs preparatory programs.}

The primary objective of student affairs preparatory programs is to educate and train new student affairs professionals. Therefore, if student affairs practitioners are to be effective leadership educators, then they need opportunities to explore leadership as an academic field of study, learn, and thereby practice the associated competencies prior to their first full-time positions in student affairs. In order to introduce leadership competencies in a systematic and consistent manner, a leadership studies course should be part of the core curriculum. However, if a required course in leadership studies is not feasible, it may be feasible to offer and encourage students to take an elective course in leadership studies. These courses do not need to be taught by student affairs faculty members. Rather, they can be offered in partnership with another department on campus where leadership is taught.

A second option is to incorporate modules focused on leadership educator competencies into the existing core curriculum, through either established or reconfigured courses. Each module should focus on different leadership educator competencies, which are reinforced as the student progresses through the entirety of the curriculum. An examination of the core curriculum would be required to determine the best way to incorporate the academic study of leadership into existing or reconfigured courses. Focusing on the methods of teaching leadership within a student affairs preparatory program was beyond the scope of this study. Therefore, at this time we are not proposing incorporating a course on andragogy or the methods of teaching leadership to others into student affairs preparatory program curricula, but acknowledge it is worth considering.

\section{Proficiency as a leadership educator should be added as a learning outcome for all graduate assistantships within a division of student affairs.}

The graduate assistantship was ranked by both Delphi panels as the most important place pre-service student affairs professionals can learn, practice, and ultimately begin to develop proficiency as a leadership educator. Because graduate assistantships are designed for pre-service student affairs practitioners to gain practical experience within a student affairs functional area, it was appropriate they be identified as one of the best opportunities for preservice student affairs professionals to put theory to practice. Yet, student affairs preparatory program faculty have very little say in what happens during the graduate assistantship experience. Traditionally, graduate assistantship supervisors provide their own training, set expectations, identify learning outcomes, determine developmental areas, and define acceptable practice for their specific graduate assistants.

Subsequently, if everyone is relying on the graduate assistantship experience to be the place where students learn and practice how to be leadership educators, then leadership educator proficiency must be included as a focused and intentional learning outcome of all assistantship experiences. Also, increased consistency between student affairs graduate assistantships across individual institutions in terms of student affairs leadership educator training and development is needed. Common expectations should be discussed and set, and the student affairs practitioners who supervise these graduate assistants need to be given the resources to develop their own 
competence as leadership educators. Only then can the supervisors be expected to be effective as they teach, train, and develop their graduate assistants to be effective leadership educators themselves.

\section{When working with pre-service student affairs} professionals, do not assume leadership educator preparation is someone else's responsibility.

This study confirmed that student affairs practitioners and faculty members see the need for leadership educator preparation during a preparatory student affairs program. However, both panels appeared to push responsibility for this preparation to the other; Practitioners (Group A) felt the development should happen in the classroom while the Faculty (Group B) felt the development should happen primarily through supervised experiential opportunities. Shifting responsibility to another does not absolve either group from their obligation to prepare competent student affairs leadership educators. Instead, increased intentional collaboration between student affairs practitioners and faculty members is needed.

\section{Internship or practica experiences should be included in student affairs preparatory programs.}

This study reaffirms the value of experiential learning, even for limited timeframes. Both Delphi panels ranked internship or practica as the second most important supervised experiential learning opportunity, behind only the graduate assistantship, for learning and practicing leadership educator competencies. The shorter duration of internships and practica enable students to work in a variety of functional areas or multiple institutions rather than exclusively relying on a single graduate assistantship for their experiential learning; thereby potentially expanding the students' practice and deepening their learning.

While student affairs leadership programming is increasingly identified as a functional area within divisions of student affairs, no one has cornered the market on leadership education. Thus, student affairs practitioners and faculty members each have a vital role to play in the education, training, and development of the next generation of leadership educators, and should take responsibility for their individual roles. Rather than working in competition, student affairs practitioners and faculty members need to work collaboratively, to reinforce and expand upon leadership educator competencies learned experientially or academically. This focus on intentional collaboration should also extend beyond student affairs professionals to include leadership studies faculty members, as they are the leadership education content experts. Ideally the result would be student affairs practitioners who are comfortable collaborating with academic faculty members and who see their professional development as leadership educators as a continual process. As Hall (2014) reported, graduate school needs to be seen as the start of a professional development journey and not the journey in its entirety. 


\section{References}

Agresti, A., \& Finlay, B. (2009). Statistical methods for the social sciences (4th ed.). Prentice Hall.

Astin, A. W., \& Astin, H. S. (2000). Leadership reconsidered: Engaging higher education in social change. W. K. Kellogg Foundation.

Blake, J. H. (2007). The crucial role of student affairs professionals in the learning process. New Directions for Student Leadership, 117, 65-72. https://doi.org/10.1002/ss.234

Brungardt, C. (1996). The making of leaders: A review of the research in leadership development and education. The Journal of Leadership Studies, 3(3), 81-95. https://doi.org/10.1177/107179199700300309

Buriak, P., \& Shinn, G. C. (1989). Mission, initiatives, and obstacles to research in agricultural education: A national Delphi using external decision-makers. Journal of Agricultural Education, 30(4), 14-23. https://doi. org/10.5032/jae.1989.04014

Burkard, A. W., Cole, D. C., Ott, M., \& Stoflet, T. (2005). Entry-level competencies of new student affairs professionals: A Delphi study. NASPA Journal, 42(3), 283-309.

Burns, J. S. (1995). Leadership studies: A new partnership between academic departments and student affairs. NASPA Journal, 32(4), 242-250.

Buschlen, E., \& Guthrie, K. L. (2014). Seamless leadership learning in curricular and cocurricular facets of university life: A pragmatic approach to praxis. Journal of Leadership Studies, 7(4), 58-6. https://doi. org/10.1002/jls.21311

Coffey, C. M. (2010). A study of competencies perceived to be important by professionals in entry-level positions within college student affairs (Unpublished doctoral dissertation). University of Central Florida, Orlando, FL.

Conger, J. A. (1992). Learning to lead: The art of transforming managers into leaders. Jossey-Bass.

Crisp, J. Pelleteir, D., Duffield, C., Adams, A., \& Nagy, S. (1997). The Delphi method? Nursing Research, 46, 116118.

Dalkey, N. C. (1969a). An experimental study of group opinion: The Delphi method. Futures, 1(5), 408-426.

Dalkey, N. C. (1969b). The Delphi method: An experimental study of group opinion. The Rand Corporation.

Delbecq, A. L., Van de Ven, A. H., \& Gustafson, D. H. (1975). Group techniques for program planning: A guide to nominal group and Delphi processes. Scott, Foreman and Company.

Dickerson, A. M., Hoffman, J. L., Anan, B. P., Brown, K. F., Vong, L. K., Bresciani, M. J., Monzon, R., \& Oyler, J. (2011). A comparison of senior student affairs officer and student affairs preparatory program faculty expectations of entry-level professionals' competencies. Journal of Student Affairs Research and Practice, 48(4), 463-479. https://doi.org/10.2202/1949-6605.6270

Dugan, J. P., \& Osteen, L. (2016). Leadership. In J. H. Schuh, S. R. Jones, \& V. Torres (Eds). Student services: A handbook for the profession (6th ed.) (pp. 408-422). Jossey-Bass. 
Dunn, A. L., Moore, L. L., Odom, S. F., Bailey, K. J., \& Briers, G. E. (2019). Leadership education beyond the classroom: Characteristics of student affairs leadership educators. Journal of Leadership Education. 18(4), 94-113. https://doi.org/10.12806/V18/I4/R10

Dunn, A. L., Moore, L. L., Odom, S. F., Briers, G. E., \& Bailey, K. J. (in press). Necessary leadership educator competencies for entry-level student affairs leadership educators. Journal of Leadership Education.

Fraenkel, J. R., \& Wallen, N. E. (2009). How to design and evaluate research in education (7th ed.). McGraw-Hill.

Franklin, K. K., \& Hart, J. K. (2007). Idea generation and exploration: Benefits and limitations of the policy Delphi research method. Innovative Higher Education, 31, 237-246. https://doi.org/10.1007/s10755-0069022-8

Guthrie, K., \& Jenkins, D. M. (2018). The role of leadership educators: Transforming learning. Information Age Publishing.

Hall, M. R. (2014). Job one 2.0: The next generation. In P. M. Magolda, \& J. E. Carnaghi. (2014). Job one 2.0: Understanding the next generation of student affairs professionals (2nd ed.). (pp. 1-10). University Press of America.

Hartman, N. S., Allen, S. J., \& Miguel, R. F. (2015). An exploration of teaching methods used to develop leaders: Leadership educator's perspectives. Leadership and Organizational Development Journal, 36(5), 454-472, https://doi.org/10.1108/LODJ-07-2013-0097

Herdlein, R. (2004). Survey of chief student affairs officers regarding relevance of graduate preparation of new professionals. NASPA Journal, 42(1), 51-71.

Herdlein, R., Riefler, L., \& Mrowka, K. (2013). An integrative literature review of student affairs competencies: A meta-analysis. Journal of Student Affairs Research and Practice, 50(3), 250-269. https://doi.org/10.1515/ jsarp-2013-0019

Hyman, R. E. (1985, April). Do graduate preparation programs address competencies important to student affairs practice? Paper presented at the annual conference of the National Association of Student Personnel Administrators. Portland, OR.

Javinar, J. M. (2000). Student life and development. New Directions for Higher Education, 111, 85-93.

Jenkins, D. M., \& Owen, J. E. (2016). Who teaches leadership? A comparative analysis of faculty and student affairs leadership educators and implications for leadership learning. Journal of Leadership Education, 15(2), 98-113, https://doi.org/1012806/V15/I2/R1

Kezar, A. J., Carducci, R. \& Contreras-McGavin, M. (2006). Rethinking the 'L' word in higher education: The revolution in research and leadership. ASHE Higher Education Report, 31(6). https://doi.org/10.1002/ aehe.3106

King, P. M. (2003). Student learning in higher education. In S. R. Komives, D. B. Woodard, Jr., \& Associates (Eds.). Student services: A handbook for the profession (4th ed.). (pp. 234-268). Jossey-Bass.

Kolb, D. A. (2015). Experiential learning: Experience as the source of learning and development (2nd ed.). Pearson Education. 
Kuk, L., \& Banning, J. (2009). Student affairs preparation programs: A competency based approach to assessment and outcomes. College Student Journal, 43(2), 492-502.

Kuk, L., Cobb, B., \& Forrest, C. (2007). Perceptions of competencies of entry-level practitioners in student affairs. NASPA Journal, 44(4), 664-691. https://doi.org/10.2202/1949-6605.1863

Linstone, H. A., \& Turoff, M. (1975). The Delphi method: Techniques and applications. Addison-Wesley Publishing.

Merriam, S. B., \& Tisdell, E. J. (2016). Qualitative research (4th ed.). John Wiley \& Sons.

Miles, J. M. (2007). Student affairs programs. In D. Wright, \& M. T. Miller (Eds.). Training higher education policy makers and leaders (pp. 45-51). Information Age Publishing.

Moore, E. L., \& Marsh, R. S. (2007). College teaching for Student Affairs professionals. New Directions for Student Leadership, 117, 3-11. https://doi.org/10.1002/ss.228

Morgan, A. C., King, D. L., Rudd, R. D., \& Kaufman, E. K. (2013). Elements of an undergraduate agricultural leadership program: A Delphi study. Journal of Leadership Education, 12(1), 140-154.

Nelson, K. A. (2010). Leadership development in student affairs graduate preparatory programs (Unpublished doctoral dissertation). University of Southern California, Los Angeles, CA.

Northouse, P. (2019). Leadership theory and practice (8th ed.). Sage.

Nuss, E. M. (2003). The development of student affairs. In S. R. Komives, D. B. Woodard, Jr., \& Associates (Eds). Student services: A handbook for the profession (4th ed.). (pp. 65-88). Jossey-Bass.

Okoli, C., \& Pawlowski, S. (2004). The Delphi method as a research tool: An example, design consideration and application. Information \& Management, 42, 15-29. https://doi.org/10.1016/j.im.2003.11.002

Rayens, M. K., \& Hahn, E. J. (2000). Building consensus using the policy Delphi method. Policy, Politics, \& Nursing Practice, 1(4), 308-315.

Roberts, D. M. (2003). Skill development among student affairs professionals in the National Association of Student Personnel Administrators region III (Unpublished doctoral dissertation). Texas A\&M University, College Station, TX.

Rogers, J. L. (1991). Leadership education in college student personnel preparation programs: An analysis of faculty perspectives. NASPA Journal, 29(1), 37-48.

Rosch, D. M., Spencer, G. L., \& Hoag, B. L. (2017). A comprehensive multi-level model for campus-based leadership education. Journal of Leadership Education, 16(4), 124-134. https://doi.org/1012806/V16/I4/A2

Rost, J. C., \& Barker, R. A. (2000). Leadership education in colleges: Toward a 21st century paradigm. Journal of Leadership Studies, 7(1), 3-12.

Schmidt, R. C. (1997). Managing Delphi surveys using nonparametric statistical techniques. Decision Sciences, 28(3), 763-774.

Thompson, M. D. (2013). Student leadership development and orientation: Contributing resources within the liberal arts. American Journal of Education Research, 1(1), 1-6. 